\title{
Home gardening and urban agriculture for advancing food and nutritional security in response to the COVID-19 pandemic
}

\author{
Rattan Lal ${ }^{1}$ (D)
}

Received: 15 May 2020 / Accepted: 19 June 2020 / Published online: 23 June 2020

(C) International Society for Plant Pathology and Springer Nature B.V. 2020

\begin{abstract}
Despite a $2.3 \%$ increase in world cereal production in 2019 over 2018, the number of people facing severe food insecurity may double from 135 million in January 2020 to 265 million by the end of 2020 . The problem of food and nutritional insecurity is severe in urban centers, where the global population is projected to increase (\%/year) by $1.84,1.63$, and 1.44 between 2015 to 2020,2020 to 2025, and 2025 to 2030, and it will increase overall from $54 \%$ in 2016 to $60 \%$ by 2030 . The number of megacities (>10 million people) will increase from 34 in 2015 to 41 by 2030 . The COVID-19 pandemic has aggravated food insecurity in urban centers because of the disruption in the food supply chain, aggravation of the physical and economic barriers that restrict access to food, and the catastrophic increase in food waste because of labor shortages. Thus, there is a need to adopt more resilient food systems, reduce food waste, and strengthen local food production. Enhancing availability at the household and community levels through home gardening and urban agriculture is an important strategy. Food production within the cities include small land farming in households, local community gardens, indoor and rooftop gardens, vertical farming, etc. Home gardening can play an important role in advancing food and nutritional security during and after the COVD-19 pandemic, while also strengthening the provisioning of numerous ecosystem services (i.e., plant biodiversity, microclimate, water runoff, water quality, human health). However, risks of soil contamination by heavy metals must be addressed.
\end{abstract}

Keywords Food and nutritional security · Home gardens · Urban agriculture · COVID-19 pandemic · Malnourishment . Undernourishment $\cdot$ Human health

\section{Introduction}

The rapid expansion of the COVID-19 pandemic, engulfing 186 countries between December 2019 and March 2020, has aggravated risks of severe/extreme food insecurity from 135 million in January 2020 to 265 million by the end of 2020 (Dongyu 2020). The severe problem of food insecurity will affect populations in both the developed and developing countries. The hotspots of food insecurity in developing countries are South Asia, SubSaharan Africa, Latin America, and the Caribbean, and the Pacific region. The twenty-first century is the era of urbanization. The global urban population of $54 \%$ in 2020

Rattan Lal

lal.1@osu.edu

1 Carbon Management and Sequestration Center, The Ohio State University, Columbus, OH 43210, USA is expected to be $60 \%$ by 2030 (Knorr et al. 2018), and urbanization is more rapid in developing than in developed countries. Urban population as percentage of the total world population in developed and developing regions, respectively, was 59.4 and 40.6 in $1950,49.8$ and 50.2 in 1970, 36.2 and 63.8 in 1990, 23.6 and 76.4 in 2018, and is projected to be 20.3 and 79.7 in 2030 and 16.8 and 83.2 in 2050 (U.N. 2018a). The world's ten most populous cities in 2020 have populations (millions) of $37.4,29.4,26.3,21.8,21.7,20.5,20.3,20.2,20.0$, and 19.2 for Tokyo, Delhi, Shanghai, Sao Paulo, Mexico City, Cairo, Dhaka, Mumbai, Beijing, and Osaka, respectively. The majority of the most populous cities are in Asia, especially in China and India. Asia and Africa are two continents which have the most people prone to both under-nourishment and malnourishment, and COVID-19 is aggravating the already serious problems of hunger and the hidden-hunger (Fig. 1). At present, there are 34 megacities (Hummel et al. 2015; U.N. 2018b), of which 
Fig. 1 Global prevalence of undernutrition and malnutrition (statistics on undernutrition and malnutrition are from $\mathrm{FAO}$, IFAD, UNICEF, WFP and WHO 2017; Ritchie and Roser 2020; WHO 2020)

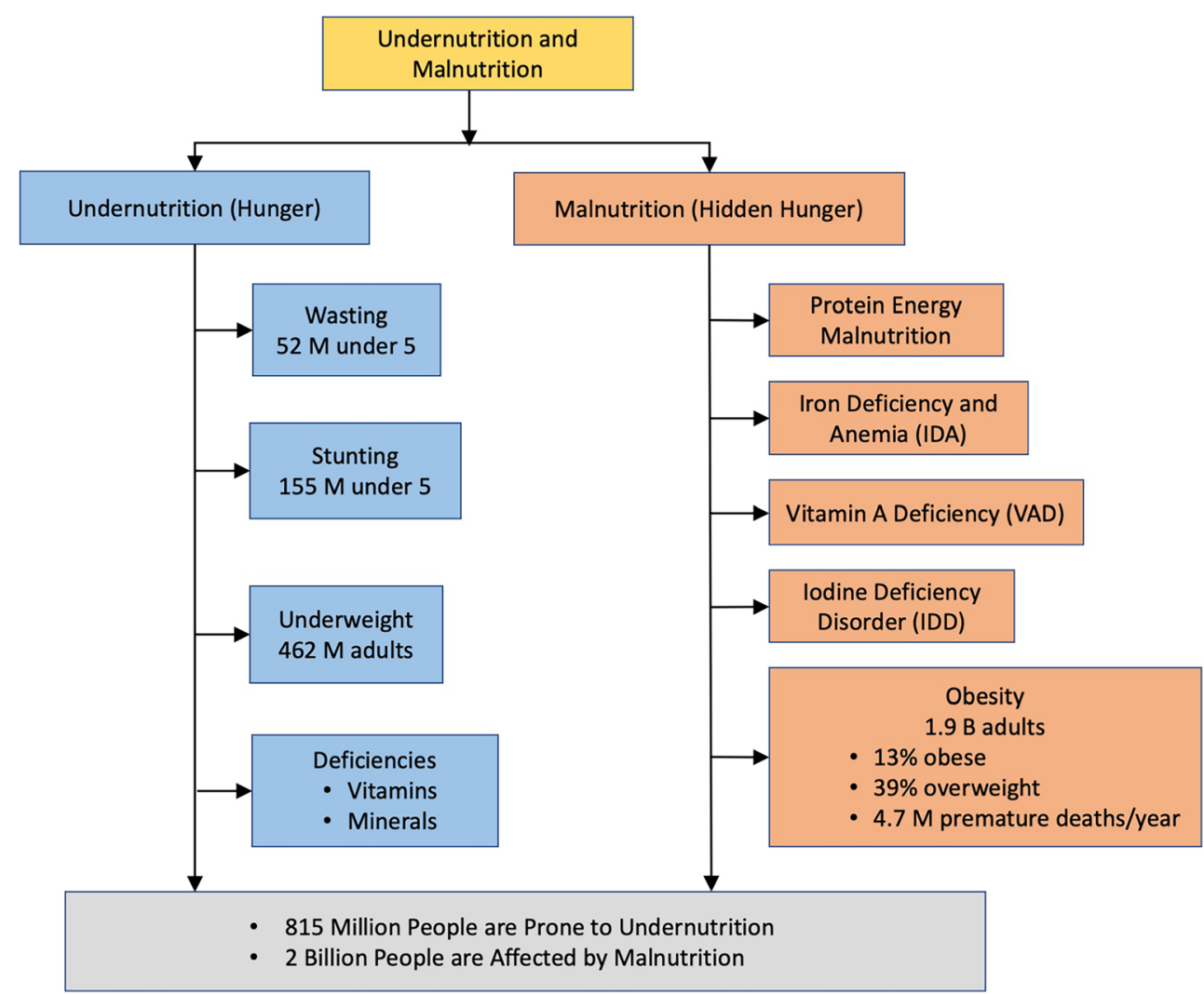

19 are in Asia. By 2030, two-thirds of the world population will be urbanized and there will be 41 megacities, of which $80 \%$ will be in low to middle-income countries. The future growth of population will almost entirely occur in urban areas of developing countries. Yet, cities in these countries are not properly designed to provide sustainable sources of adequate and nutritious food for large population even without the disruptions such as that caused by the COVID-19 virus. Major disruptions in food supply chain caused by the COVID-19 pandemic have aggravated the already existing severe problems of hunger and malnutrition along with food wastage. Unplanned or adhoc urbanization also has drastic impacts on the environment (i.e., the heat island effect, high runoff, inundation), and these problems are aggravated by the changing climate. A major challenge created by the COVID-19 pandemic is disrupting access to fresh and nutritious food at affordable prices to large and growing urban population. The problem is worsened by the lack of or weak infrastructure and poor institutional support. Thus, there is a need to adopt more resilient food systems, reduce food waste along the supply chain, and strengthen the growth of local agricultural capabilities through home gardening and urban agriculture (HGUA). The specific objective of this article is to describe: 1) properties of urban soils and their suitability for growing food, 2) home gardens and urban agriculture for food and nutritional security, 3) ecosystem services provisioned by HGUA, 4) soil management options to reduce risks of contamination of urban soils by heavy metals and other pollutants, and 5) the nexus thinking of waste and water management based on the concept of recycling nutrients and water for producing food, and advancing the Sustainable Development Goals (SDGs) of the United Nations (U.N. 2015) through HGUA.

\section{Properties of Anthrosols and Technosols and their suitability for growing food}

Urban soils are called Anthropic soils, Anthrosols, or Technosols (FAO/UNESCO 1990) because anthropogenic control of pedogenic processes leads to drastic alterations in soil properties. In general, urban soils comprise of highly disturbed and manipulated materials altered through mixing, filling, transportation, and other perturbations caused by construction-related activities. Yet, urban soils vary widely because of differences in site history, population density, and cultural and socioeconomic conditions. Urban soil horizons are irregular and comprise a mixture of soils, which may contain high contents of stones, gravels, and artifacts. Important attributes of urban 
soils, in the context of HGUA are the following: high heterogeneity, large temporal and special variability, presence of artifacts, and contamination by inorganic and organic pollutants. These soils are characterized by poor physical properties (e.g., high bulk density, low water infiltration rate, low plant available water capacity, and susceptibility to drought), unfavorable chemical properties (e.g., low soil fertility, nutrient imbalance, and low soil organic carbon concentration and stock), and low activity and species diversity of soil biota. Therefore, restoration and sustainable management of the physical, chemical, and biological properties of urban soils is critical to improving agronomic productivity and nutritional quality of vegetables and fruits grown on these soils. Application of compost, mulch, and other sources of biomass-carbon (i.e., lawn clippings, leaf litter, household waste) is essential to improving soil quality and functionality and alleviating soil-related constraints to HGUA.

\section{Strengthening local food production by home gardening and urban agriculture}

The COVID-19 pandemic has disrupted the food supply chain. Thus, it is critically important to strengthen local food production at the household and community levels. The home garden is a farming system which combines different physical, social and economic functions on land around the family home to supplement supply of fresh food at the household level. Logistically, home gardens provide easy day-to-day access to fresh vegetables and fruits, leading to enriched and balanced diets by supplementing proteins, vitamins, and minerals (Galhena et al. 2013). Through supply of medicinal herbs and an opportunity for physical activity, home gardens are also important to human health and wellbeing. Thus, home gardens can improve food security, diversity, nutritious value, and the microenvironment around the family home.

Urban agriculture (UA) is defined as all forms of agricultural production (food and non- food) occurring within or around cities (Wagstaff and Wortman 2015). UA strengthens many ecosystem services, such as improving human health, food access to local communities, income and jobs along with economic prospects, aesthetical value and beauty, education about farming, and community resilience (Fig. 2) (Oberholtzer et al. 2014; Santo et al. 2016; Thomas 2014). UA may comprise ground-based outdoor urban gardens and farms, hydroponic or aquaponic indoor production through skyfarming, rooftop gardens and farms, landscaping and nursery businesses, and urban livestock (Little 2019). Community gardens refer to spaces that provide agriculture environment within the city limits to grow vegetables and fruits and raise livestock. These gardens are owned or farmed by the members of the community or sub-divided into allotments cultivated by individual members (Corkery 2004).

\section{Home gardens and urban agriculture for food and nutritional security}

The conventional system of bringing food into large cities, over an average distance of 800 to $1500 \mathrm{~km}$, involves a large amount of energy and is vulnerable to disruptions such as that caused by COVID-19 (Altieri 2019). Thus, there is an urgent need for adopting resilient food systems for meeting a partial food needs through a systematic development of HGUA. UA is already producing about 15 $20 \%$ of the world's food supply, and this can play an even more critical role in achieving food security during a global crisis such as that created by the COVID-19 virus. Small scale UA can produce high crop yields through judicious management of inputs needed for achieving sustainability (McDougall et al. 2019). The percent of families engaged in UA varies from $10 \%$ in some large cities in North America to $80 \%$ in some smaller Siberian and Asian cities (Thomas 2014). In 2013, 42 million American households were actively practicing HGUA by growing their own food either at home or in community gardens (Algert et al. 2016).

During the COVID-19 pandemic, innovative HGUA systems are critical to addressing the following issues both in developing and developed economies: 1) large populations living in mega- and gigacities with large food demand, 2) high food waste at all steps of the supply chain and long food mileage, 3) undernourishment and malnourishment because of the poor nutritional quality of the food (Fig. 1), 4) disruptions in the food supply chain, and 5) low income as a result of the lockdown. A system-based and wholistic approach through HGUA can produce food within urban centers, including in and on urban buildings.

In addition to the large and growing megacities in developing countries, there are also several megacities in the developed countries of North America, Europe, and Australia where practicing HGUA is as an important solution to the food crisis as it is in developing countries. Some large cities and their populations (millions) in developed countries include New York (18.8), Moscow (12.5), Los Angeles (12.4), Paris (12.3), London (9.0), Sydney (5.0), etc. These cities have specific examples of HGUA, including vertical farming, which uses hydroponics and aquaponics (Despomier 2018). Scientific HGUA (i.e., vertical farming) has the potential to alleviate food and nutritional insecurity, while not only reducing demands on finite natural resources but also providing urban 
Fig. 2 Food, environmental, economic, and ecosystem service benefits of home gardens and urban agriculture

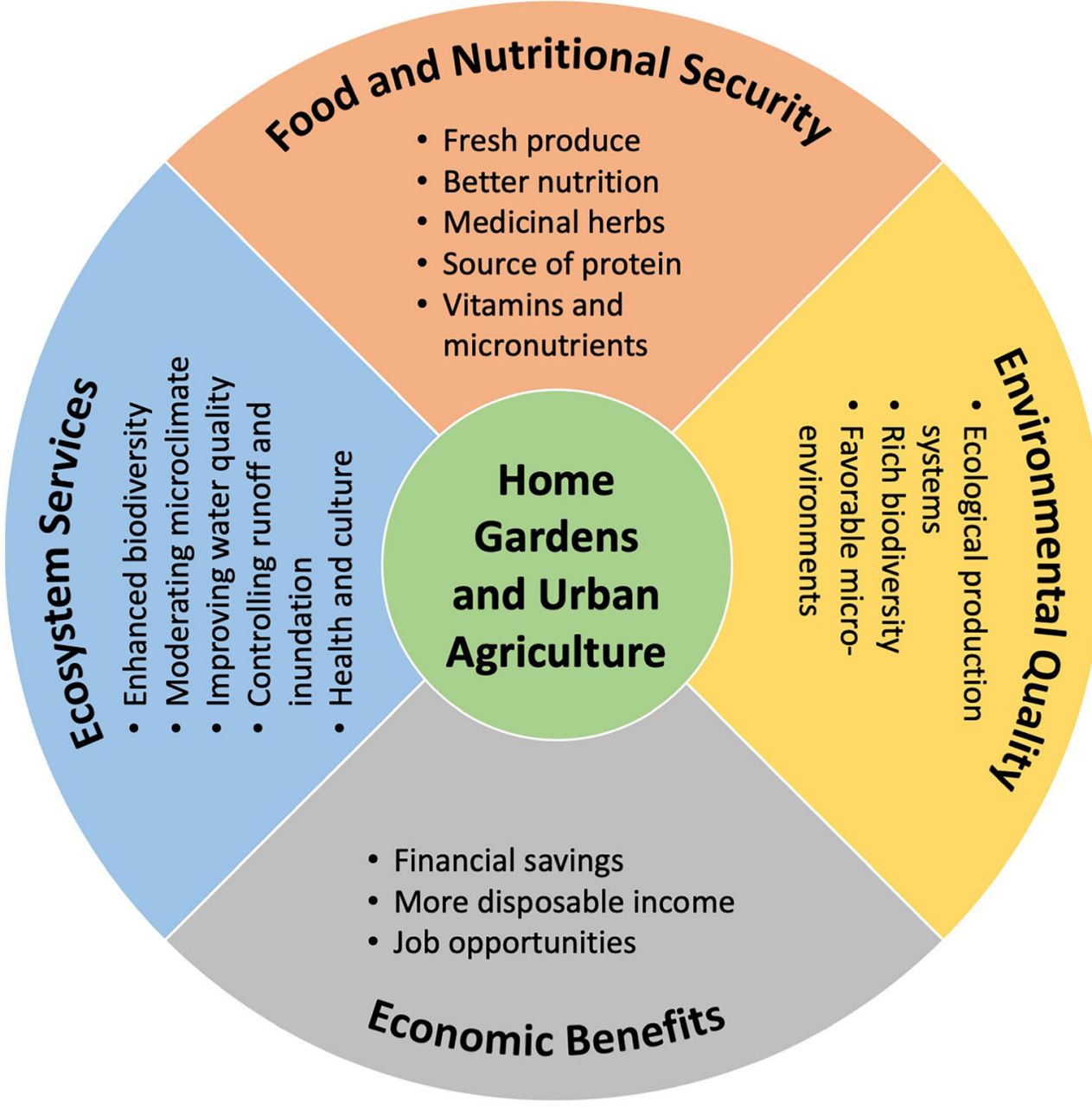

populations with diverse, sustainable, safe, and nutritious food.

\section{Contaminants in urban soils}

Soil contamination by heavy metals [i.e., lead $(\mathrm{Pb})$, arsenic (As), and cadmium (Cd)] and organic pollutants [i.e., polycyclic aromatic hydrocarbons (PAHs), antibiotics, and petroleum products] are among the major constraints limiting the use of urban soils for food production (Menefee and Hettiarachichi 2018). These problems must be addressed to produce healthy and safe food. Indeed, with adequate management and bioremediation, the pathway from contaminated soil to humans via food can be minimized, and high yield obtained with judicious management of inputs (McDougall et al. 2019). Bioavailability of heavy metals and organic pollutants can be reduced by input of soil amendments including compost, mulch, recycling of the biomass and use of engineered media, which enhance soil health and promote activity and species diversity of soil biota. Replacement soil can be produced through urban waste that can be added into contaminated soil (Brown 2018).

\section{Impact on ecosystem services and sustainable development goals of the United Nations through Nexus thinking about waste management}

In addition to increasing access to fresh and nutritious food, HGUA also strengthen supporting, provisioning, regulating, and cultural/social ecosystem services or ESs (Fig. 2). Site-specific examples of these ESs include: 1) soil formation and primary production for supporting services, 2) food, fiber, fresh water and infra-structure foundation of provisioning services, 3) micro-climate modification, flood control, water purification, soil bioremediation and decontamination for regulating services, and 4) aesthetical, spiritual, recreational, and social for cultural services (Shuster and Dadio 2018). In accord with the strengthening of ESs, HGUA has also positive impacts on the SDGs of the U.N. Urban waste, a major 
environmental hazard and source of pollution, can become an asset by developing a cyclic economy. Compost made from waste is an essential amendment to restore soil health, enhance productivity, and improve the nutritional quality of food grown under HGUA systems. Sustainable management of soils by practicing HGUA can simultaneously enhance humanity's culture, civilization, livelihood and health (Minami 2009) and create sustainable communities (Sullivan 2010).

\section{Innovative Management of Urban Soils for home gardens and urban agriculture}

The focus of managing urban soils for HGUA is on agronomic productivity, nutritional quality, and the safety of food products. Vertical farming, based on a cyclic economy involving aquaponics and hydroponics, is an innovative option (Despomier 2018). Just as in agricultural lands, indiscriminate use of chemicals, water, and other inputs must be avoided. Similarly, judicious use of inputs is critical to obtaining high yields and safe produce in home gardening (McDougall et al. 2019). Because of heavy human traffic, the risks of soil compaction must be minimized by improving and sustaining soil structure of the surface layer by mulching and use of compost to enhance the activity of earthworms and other biota. Scarcity of good quality topsoil can be addressed by using synthetic soils. Rather than sprinklers, drip irrigation may be essential to improving water use efficiency.

\section{Conclusions}

- The COVID-19 pandemic has disrupted the food supply chain and globally aggravated undernourishment and malnourishment, but especially in developing countries

- Food production within cities by practicing HGUA can create resilient food systems while reducing food waste along the supply chain.

- Restoration of the quality of urban soils, by use of compost and other organic amendments, is important to improving productivity, enhancing nutritional quality, ensuring safety, improving human health and strengthening numerous ESs.

- Soil restoration can be accelerated by using synthetic soils made from biowaste and organic materials.

- Sky farming; based on circular economy and using aquaponics and hydroponics, is an innovate and new form of urban agriculture.

- Practicing HGUA is an important strategy to advance SDGs of the U.N.

\section{Compliance with ethical standards}

Conflicts of interest The author declares that there was no conflict of interest regarding this article.

\section{References}

Algert, S., Diekmann, L., Renvall, M., \& Gray, L. (2016). Community and home gardens increase vegetable intake and food security of residents in San Jose, California. California Agriculture, 70(2), 77-82. https://doi.org/10.3733/ca.v070n02p77.

Altieri, M. (2019). How urban agriculture can improve food security in US cities. Phys Org. https://phys.org/news/2019-02-urbanagriculture-food-cities.html

Brown, S. (2018). Making soils from urban wastes. In R. Lal \& B. A. Stewart (Eds.), Urban Soils (pp. 215-227). Boca Raton: CRC Press.

Corkery, L. (2004). Community gardens as a platform for education for sustainability. Australian Journal of Environmental Education, 20(1), 69-75. https://doi.org/10.1017/S0814062600002317.

Despomier, D. (2018). Vertical farming using hydroponics and aquaponics. In R. Lal \& B. A. Stewart (Eds.), Urban Soils (pp. 313-327). Boca Raton: CRC Press.

Dongyu, Q. (2020). Senior officials sound alarm over food insecurity, warning of potentially 'biblical' famine, in briefings to security council title. United Nations Security Council. https://www.un.org/ press/en/2020/sc14164.doc.htm

FAO, IFAD, UNICEF, WFP \& WHO. (2017). The state of food security and nutrition in the world 2017: Building resilience for peace and food security. Rome: FAO http://www.fao.org/3/a-I7695e.pdf.

FAO/UNESCO. (1990). Soil map of the world: Revised legend with corrections and updates. World soil resource report 60. Rome: FAO.

Galhena, D. H., Freed, R., \& Maredia, K. M. (2013). Home gardens: A promising approach to enhance household food security and wellbeing. Agriculture and Food Security, 2(1), 8. https://doi.org/ 10.1186/2048-7010-2-8.

Hummel, J. R., Martinez-Moyano, I., Lewis, L. P., \& Schneider, J. L. (2015). Feeding the Future's Cities: Challenges in an Uncertain World. http://www.fao.org/fileadmin/templates/ags/docs/MUFN/ CALL_FILES_EXPERT_2015/CFP3-15_Full_Paper.pdf

Knorr, D., Khoo, C. S. H., \& Augustin, M. A. (2018). Food for an urban planet: Challenges and research opportunities. Frontiers in Nutrition, 4, 73. https://doi.org/10.3389/fnut.2017.00073.

Little, N. (2019). What is urban agriculture? University of Maryland Extension. University of Maryland Extension. https://extension. umd.edu/learn/what-urban-agriculture

McDougall, R., Kristiansen, P., \& Rader, R. (2019). Small-scale urban agriculture results in high yields but requires judicious management of inputs to achieve sustainability. Proceedings of the National Academy of Sciences of the United States of America, 116(1), 129-134. https://doi.org/10.1073/pnas.1809707115.

Menefee, D. S., \& Hettiarachichi, G. M. (2018). Contaminants in urban soils: Biodiversity and transfer. In R. Lal \& B. A. Stewart (Eds.), Urban Soils (pp. 175-187). Boca Raton: CRC Press.

Minami, K. (2009). Soil and humanity: Culture, civilization, livelihood and health. Soil Science \& Plant Nutrition, 55(5), 603-615. https:// doi.org/10.1111/j.1747-0765.2009.00401.x.

Oberholtzer, L., Dimitri, C., \& Pressman, A. (2014). Urban agriculture in the United States: Characteristics, challenges, and technical assistance needs. Journal of Extension, 52(6), v52-6a1.

Ritchie, H., \& Roser, M. (2020). Obesity. Our World in Data. https:// ourworldindata.org/obesity 
Santo, R., Palmer, A., \& Kim, B. (2016). Vacant lots to vibrant plots: A review of the benefits and limitations of urban agriculture. https:// doi.org/10.13140/RG.2.2.25283.91682

Shuster, W. D., \& Dadio, S. (2018). An applied hydropedological perspective onthe rendering of ecosystem services from urban soils. In R. Lal \& B. A. Stewart (Eds.), Urban Soils (pp. 261-263). Boca Raton: CRC Press.

Sullivan, R. (2010). Local food for sustainable communities. ECOS: Science for Sustainability. http://www.ecosmagazine.com/paper/ EC152p18.htm

Thomas, G. (2014). Growing greener cities in Latin America and the Caribbean: An FAO report on urban and peri-urban agriculture in the region. Rome, Italy. http://www.fao.org/3/a-i3696e.pdf

U.N. (2015). Transforming our world: The 2030 agenda for sustainable development. A/res/70/1. New York: UN General Assembly https:// www.refworld.org/docid/57b6e3e44.htm.

U.N. (2018a). The World's Cities in 2018-Data Booklet (ST/ESA/ SER.A/417). United Nations, Department of Economic and Social Affairs, Population Division. https://www.un.org/en/events/ citiesday/assets/pdf/the worlds cities in 2018 data booklet.pdf

U.N. (2018b). World urbanization prospects (ST/ESA/SERA/420). New York: United Nations, Department of Economic and Social Affairs, Population Division.

Wagstaff, R. K., \& Wortman, S. E. (2015). Crop physiological response across the Chicago metropolitan region: Developing recommendations for urban and peri-urban farmers in the north central US. Renewable Agriculture and Food Systems, 30(1), 8-14. https://doi. org/10.1017/S174217051300046X.

WHO. (2020). Malnutrition. Fact Sheets. https://www.who.int/newsroom/fact-sheets/detail/malnutrition

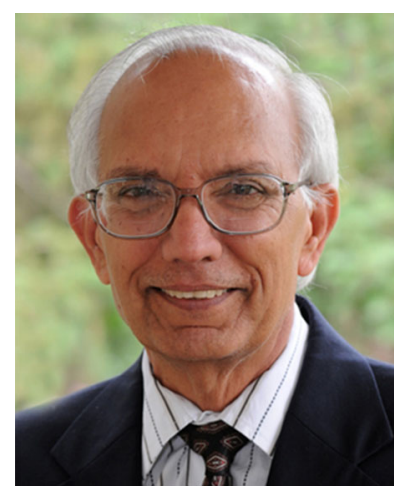

Rattan Lal Ph.D., is a Distinguished University Professor of Soil Science and Director of the Carbon Management and Sequestration Center at The Ohio State University, and an Adjunct Professor of the University of Iceland. He received a B.S. from Punjab Agricultural University, Ludhiana, India (1963); M.S. from Indian Agricultural Research Institute, New Delhi, India (1965); and Ph.D. from the Ohio State University, Columbus, Ohio (1968). He served as Sr. Research Fellow with the University of Sydney, Australia (1968-69), Soil Physicist at IITA, Ibadan, Nigeria (1970-87), and Professor of Soil Science at OSU (1987to date). He has authored/co-authored 955 refereed journal articles and 543 book chapters and has written 22 and edited/co-edited 76 books. He was included in the Thomson Reuters list of the World's Most Influential Scientific Minds (2014-2016), and he is among Clarivate's Highly Cited Researchers in Agriculture (2014-2019). He has received an Honoris Causa degree from seven universities in Europe, USA and Asia; the Medal of Honor from UIMP, Santander, Spain (2018); the Distinguished Service Medal of IUSS (2018); and is fellow of the five professional societies. Dr. Lal has mentored 112 graduate students and 180 visiting scholars from around the world. He was President of the World Association of Soil and Water Conservation (1987-1990), International Soil and Tillage Research Organization (1988-1991), Soil Science Society of America (2006-2008), and the International Union of Soil Sciences (2017-2018). He is laureate of the GCHERA World Agriculture Prize (2018), Glinka World Soil Prize (2018), the Japan Prize (2019), the U.S. Awasthi IFFCO Prize (2019), and the World Food Prize (2020). 